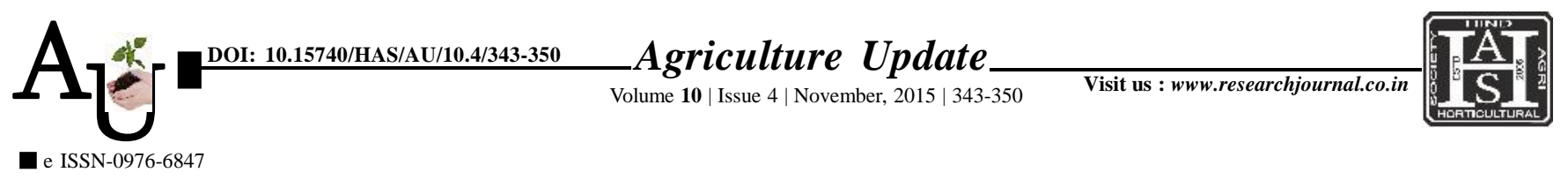

\title{
Regerach Aвtcli: A study on constraints perceived by the farmers in adoption of moongbean production technology in Vadodara and Chhotaudaipur district of Gujarat
}

B.L. DHAYAL, C.R. PATEL AND B.M. MEHTA

Article Chronicle:

Received :

12.08.2015;

Revised :

11.10.2015;

Accepted :

25.10.2015

KEY WoRds :

Moongbean,

Constraints,

Adoption, Production technology
SUMMARY : Mungbean can be eaten solely, or combined with rice to make khichari, or combined with vegetables and greens to make hearty soups or grind into flour to be used to make crepes or added to breads. Turmeric, cumin, dried ginger and coriander are some spices that work very well with mungbean. Study revealed that majority of respondents $(60.00 \%)$ perceived constraints moderately, 23.00 per cent perceived constraints upto high extent whereas, remaining 17.00 per cent perceived constraints upto low extent regarding following improved package of practices of moongbean cultivation. It is recommended that intensive efforts be made to conduct more number of FLDs on moongbean production technology so as to bring more farmers under FLDs umbrella. Thus the difference as depicted in the study results with regards to knowledge and adoption.In view of the findings, it is suggested that subject matter specialist of K.V.K., should visit the field more frequently and assure that the adoption of all the practices (as a package) at the farmer's field.

How to cite this article : Dhayal, B.L., Patel, C.R. and Mehta, B.M. (2015). A study on constraints perceived by the farmers in adoption of moongbean production technology in Vadodara and Chhotaudaipur district of Gujarat. Agric. Update, 10(4): 343-350.
Author for correspondence :

\section{B.L. DHAYAL}

Krishi Vigyan Kendra, VADODARA (GUJARAT) INDIA

Email: dhayalextn@ yahoo.co.in

See end of the article for authors' affiliations 